\title{
HUBUNGAN ANTARA KARAKTERISTIK INDIVIDU PETANI DENGAN KOHESIVITAS KELOMPOK TANI TANAMAN OBAT
}

\author{
Iriana Bakti ${ }^{1}$, Evi Novianti ${ }^{2}$, Centurion Chandratama Priyatna ${ }^{3}$, dan Heru Ryanto Budiana ${ }^{4}$ \\ 1,2,3,4 Universitas Padjadjaran
}

\begin{abstract}
ABSTRAK
Petani merupakan salah satu elemen penting dalam proses pengelolaan tanaman obat di Jawa Barat. Mereka berusaha berinteraksi, baik dengan sesama anggota kelompoknya, maupun dengan kelompok lain, serta dengan para petugas yang membinanya, sehingga dari interaksi tersebut terbangun kohesivitas kelompok di antara mereka. Tujuan dari penelitian ini adalah untuk mengetahui: 1) hubungan antara jenis kelamin petani dan kohesivitas kelompok tani, 2) hubungan lamanya bertani dengan kohesivitas kelompok tani, dan 3) hubungan antara luas lahan yang dimiliki dan kohesivitas kelompok tani. Metode yang digunakan dalam penelitian ini survei eksplanatif. Teknik analisis menggunakan korelasional, dan rumus statistik untuk menguji hipotesis adalah rank order Spearmans. Teknik pengumpulan data menggunakan angket, pedoman wawancara, dan studi kepustakaan. Populasi penelitian ini adalah kelompok tani tanaman obat di Jawa Barat. Teknik sampling yang digunakan adalah multy stage cluster sampling. Sampel penelitian berasal dari Kabupaten Bogor (K. T Lindung harapan dan K. L Tani Mekar), Kabupaten Sukabumi (Gapoktan Kamuningjaya), dan Kabupaten Majalengka (KT Melati, KT Dahlia, dan Cempaka Mukti). Seluruhnya ada 114 anggota. Hasil penelitian ini antara lain: 1) terdapat hubungan antara jenis kelamin petani dengan kohesivitas kelompok tani tanaman obat, 2) terdapat hubungan antara lamanya bertani dengan kohesivitas kelompok tani, dan 3) terdapat hubungan antara luas lahan yang dimiliki dengan kohesivitas kelompok tani. Secara umum karakteristik individu petani memiliki hubungan yang positif dengan kohesivitas kelompok tani. Petani mayoritas wanita pada umumnya memiliki kesamaan pandangan, senang pada kegiatan kelompok, menjadikan pertemuan kelompok sebagai wadah belajar untuk meningkatkan wawasan, pembagian tugas, dan kerja sama. Demikian pula dengan luas lahan yang dimiliki, relatif terbatas, menjadikan anggota kelompok tani tersebut merasa senasib dan tidak terdapat gap kepemilikan tanah, sehingga mereka bisa bekerja sama untuk mengelola tanaman obat disesuaikan dengan lahan yang ada. Lamanya bertani tidak ada hubungannya dengan kohesivitas, karena komoditas yang ditanam bukan komoditas unggulan.
\end{abstract}

Kata-kata Kunci: Karakteristik individu, kohesivitias, kelompok tani, pengelolaan, tanaman obat

\section{RELATIONSHIP BETWEEN FARMERS' INDIVIDUAL CHARACTERISTICS WITH KOHESIVITY OF MEDICINE PLANT FARMER GROUP}

\begin{abstract}
Farmer is one of the important elements in the management process of medicinal plants in West Java. They try to interact, both with fellow members of her group, as well as with other groups, as well as with the officers who built it, so from the interaction group cohesivity woke up between them. The purpose of this research is to find out: 1) relationship between the sex of the peasants and farmers group cohesivity, 2) relationship between the length of time of farmers with cohesivity group of farmers, and 3) relationship between land area owned and cohesivity of farmers group. The methods used in this research was explanative survey, corelational analytical techniques, and statistical formulas to test the hypothesis. Data collection techniques using question form, guidelines for interviews, and literature studies. The population group of farmers of medicinal plants in West Java, multy-stage cluster sampling techniques, with samples used were from Bogor regency (K. T Lindung harapan dan K. L Tani Mekar), Kabupaten Sukabumi (Gapoktan Kamuningjaya), dan Kabupaten Majalengka (KT Melati, KT Dahlia, dan Cempaka Mukti). There are 114 members entirely. Research results: 1) there is a relationship between the sex of the peasant farmers group cohesivity with medicinal plants, 2) there is a relationship between the length of farming with the cohesivity group of farmers, and 3) there is a relationship between land area owned by cohesivity farmers group. In General, the individual characteristic of farmer has a positive relationship with the cohesivity group of farmers. Majority of the farmers are women, generally have the same view, happy with group activities, making group meeting studied as a container to improve insight, division of tasks, and cooperation. Similar land area owned that relatively limited, making the farmers group members feel in the same boat. There was no gap of land ownership so they could work together to administer medicinal plants adapted to the land. Length of farming has nothing to do with cohesiviy, because commodities are planted instead of the flagship commodities.
\end{abstract}

Keywords: Strategy, brand, rebranding, radio, case study

Korespondensi: Dr. Iriana Bakti, Universitas Padjadjaran, Jl. Raya Bandung-Sumedang Km 21, Jatinangor 45363. Email: irianabaktipr@gmail.com 


\section{PENDAHULUAN}

Tanaman obat merupakan salah satu komoditas yang saat ini dijadikan tanaman alterrnatif untuk berbagai keperluan. Sebagai tanaman alternatif, tanaman obat memiliki berbagai manfaat, seperti untuk pengobatan, sumber gizi keluarga, sumber ekonomi tambahan, dan sebagainya, sehingga banyak petani mulai mencoba menanam, memelihara, dan melestarikan tanaman ini.

Pengelolaan tanaman obat dilakukan oleh individu-individu yang tergabung ke dalam kelompok tani, sehingga aktivitasnya terkoordinasikan di bawah bimbingan ketua kelompoknya, dan dibina oleh pembina dari dinas/instansi terkait. Bimbingan dan pembinaan ini sangat penting untuk menambah pengetahuan dan wawasan petani, sehingga mereka dapat mengelola tanaman obat tersebut sebagai salah satu solusi permasalahan yang dihadapi terutama di bidang kesehatan dan kesejahteraan keluarganya. Selain itu, dalam pengelolaan tanaman obat, karakteristik individu petani berperan cukup signifikan dalam membangun kesepahaman dan kerja sama di antara mereka. Hal ini bisa dilihat dari hasil penelitian yang menyatakan bahwa:

"Karakteristik petani tanaman obat bisa dilihat dari jenis kelamin yang mayoritas anggota kelompok tani tanaman obat ternyata perempuan yang tingkat pendidikkannya SD. Mereka menjadi petani tanaman obat mayoritas sekitar 1-2 tahun dan dalam sebulan terakhir tidak pernah ke luar dari daerahnya. Untuk mencari informasi sebagian besar memanfaatkan televisi, radio dan surat kabar. Adapun jenis tanaman obat yang ditanam oleh mereka kebanyakan adalah jahe, kunyit, dan temu lawak. Sebagian besar petani memiliki lahan di bawah $1 / 4$ hektar (Bakti, dkk., 2015: 46).

Petani merupakan salah satu elemen penting dalam proses pengelolaan tanaman obat di Jawa Barat. Mereka berusaha berinteraksi, baik dengan sesama anggota kelompoknya, maupun dengan kelompok lain, serta dengan para petugas yang membinanya, sehingga dari interaksi tersebut terbangun kohesivitas kelompok di antara mereka. Berdasarkan hasil penelitian sebelumnya diperoleh data, bahwa:

"Tingkat kohesivitas petani tanaman obat dikategorikan tinggi. Hal ini dapat dilihat dari semua anggota kelompok tani memiliki kesamaan pandangan tentang pentingnya menanam tanaman obat dengan pihak lain, sebagian besar merasa senang mengikuti kegiatan kelompok sebagai wadah belajar mengelola tanaman obat untuk meningkatkan wawasan tentang tanaman obat. Selain itu, para petani tanaman obat juga menyatakan dalam setiap kegiatan pengelolaan tanaman obat selalu ada pembicaraan dan pembagian tugas yang harus dilakukan oleh anggotanya, dan setiap kegiatan pengelolaan tanaman obat selalu dikerjakan bersama-sama" (Bakti, dkk., 2015: 49).

Karakteristik petani tanaman obat Kabupaten Bogor (K. T Lindung harapan dan K. L Tani Mekar), Kabupaten Sukabumi (Gapoktan Kamuningjaya), dan Kabupaten Majalengka (KT Melati, KT Dahlia, dan Cempaka Mukti) pada umumnya relatif sama, yaitu didominasi oleh perempuan, lamanya bertani tanaman obat secara intensif masih kurang, dan luas lahan yang digarap untuk tanaman obat relatif sempit. Hal ini disebabkan garapan tanaman obat cenderung kerjaan sampingan untuk mengisi waktu luang, walaupun beberapa di antaranya serius juga menggarap tanaman obat tersebut, sehingga kompetensi petani tanaman obat ini cenderung rendah. Padahal menurut Manyamsari dan Mujiburrahmad (2014: 70), "karakteristik petani yang berhubungan secara signifikan dengan kompetensi antara lain adalah luas lahan....".

Pada umumnya kekuatan atau keeratan kelompok tani cenderung pada dasarnya ditentukan antara lain oleh kerja sama di antara anggota-anggotanya yang didasarkan pada perasaan dan minat yang sama terhadap tanaman obat. Namun demikian, walaupun mereka sudah mengenal tanaman obat, dalam pengelolaannya mareka harus banyak belajar dan berinteraksi agar dapat mengemukakan gagasan/pendapatnya tentang pengelolaan 
tanaman obat tersebut, sehingga di antara mereka terjalin hubungan yang harmonis, karena menurut Shaw dalam Hariadi (2011: 27 28), "anggota kelompok pada kelompok yang kohesinya tinggi lebih energik dalam aktivitas kelompok, dan akan merasa senang ketika kelompok berhasil dan merasa sedih ketika kelompok gagal"'.

Berdasarkan hal di atas, penulis tertarik untuk melakukan penelitian yang berkaitan dengan hubungan antara karakteristik individu petani dengan kohesivitas kelompok tani tanaman obat.

\section{METODE PENELITIAN}

Metode yang digunakan dalam penelitian ini survei eksplanatif. Teknik analisis menggunakan korelasional, dan rumus statistik untuk menguji hipotesis adalah rank order Spearmans. Teknik pengumpulan data menggunakan angket, pedoman wawancara, dan studi kepustakaan. Populasinya kelompok tani tanaman obat di Jawa Barat, teknik samplingnya multy stage cluster sampling. Sampelnya di Kabupaten Bogor (K. T Lindung harapan dan K. L Tani Mekar), Kabupaten Sukabumi (Gapoktan Kamuningjaya), dan Kabupaten Majalengka (KT Melati, KT Dahlia, dan Cempaka Mukti). Seluruhnya ada 114 anggota.
Proses penelitian dilakukan dengan cara mengukur variabel karakteristik individu dengan indikatornya adalah jenis kelamin, luas lahan, dan lamanya bertani. Variabel lainnya adalah kohesivitas kelompok, dengan indikatornya tingkat kohesivitas berdasarkan kesamaan pandangan, perasaan mengikuti kegiatan kelompok, penilaiannya terhadap kelompok tani sebagai wadah, pembagian tugas, dan kerja sama. Kemudian data dari variabel penelitian tersebut, dianalisis dengan menggunakan teknik analisis deskriptif, dan teknis analisis inferensial untuk menguji hipotesinya dengan menggunakan Rank Spearman's.

Berdasarkan pada tabel 1 ternyata sebagian besar responden yang terlibat dalam kelompok tani tanaman obat berjenis kelamin perempuan (70\%) selanjutnya yang berjenis kelamin Lakilaki (30\%). Besarnya perempuan yang terlibat dalam kelompok tani tanaman obat diduga mereka sebagai istri petani/anggota keluarga tani harus terlibat langsung dalam kegiatan usaha tani tanaman obat untuk membantu kehidupan dan penghidupan keluarganya. Selain itu, sebagai anggota masyarakat peranan perempuan harus meningkatkan pengetahuan atau keterampilan sesuai dengan kebutuhannya, yang pada akhirnya pengetahuan dan keterampilan tersebut diperoleh setelah dirinya bergabung ke dalam kelompok tani tanaman

Tabel 1 Jenis Kelamin Responden

\begin{tabular}{ccc}
\hline Jenis Kelamin & Frekuensi & $\%$ \\
\hline Laki-laki & 34 & $30 \%$ \\
Perempuan & 80 & $70 \%$ \\
\hline Jumlah & 114 & $100 \%$ \\
\hline
\end{tabular}

Sumber: Data Olahan Penulis

\section{Tabel 2 Lama Bertani}

\begin{tabular}{ccc}
\hline Lama Bertani & Frekuensi & $\%$ \\
\hline 1-2 Tahun & 82 & $75 \%$ \\
3-4 Tahun & 8 & $7 \%$ \\
5 Tahun Lebih & 19 & $17 \%$ \\
\hline Jumlah & 109 & $100 \%$ \\
\hline
\end{tabular}

Sumber: Data Olahan Penulis 
obat.

Berdasarkan pada tabel 2, mayoritas responden memiliki pengalaman lama bertani 1-2 tahun yaitu sebanyak 82 responden (75\%), responden yang memiliki pengalaman lama bertani 3-4 tahun sebanyak 8 responden (7\%), dan responden yang memiliki pengalaman lama bertani 5 tahun lebih sebanyak 19 responden $(17 \%)$. Dilihat dari lamanya bertani ini, mayoritas responden yang berkecimpung dalam pengelolaan tanaman obat ternyata masih belum lama. Hal ini diduga bahwa tanaman obat bukan merupakan komoditas pertanian utama yang menjadi prioritas petani, tetapi komoditas sampingan untuk menunjang kebutuhan keluarga. Jadi sebagian besar petani belum lama mengelola tanaman obat ini dengan sistematis.

Berdasarkan pada tabel 3 dari jumlah data yang diperoleh. Untuk luas lahan yang dimiliki oleh para petani obat mayoritas dibawah $1 / 4$ ha $(58 \%)$, sedangkan $1 / 4-1 / 5$ ha $(18 \%)$ dan 1 ha/ lebih sebesar $25 \%$. Dengan demikian, luas lahan yang digunakan untuk menanam tanaman obat sangat sempit, hal ini diduga adanya keterbatasan kepemilikan lahan pada petani secara umum, sehingga alokasi penggunaan lahan yang digunakan untuk menanam tanaman obat pun menjadi sangat terbatas. Keterbatasan lahan ini akan berdampak pada produktivitas usaha tani tanaman obat.

Berdasarkan tabel 4, ternyata tingkat kohesivitas kelompok tani tanaman obat dikategorikantinggi(98\%). Hal inimenunjukkan bahwa Kohesivitas Kelompok Tani sudah cukup baik. Tingginya tingkat kohesivitas kelompok tani tersebut diduga di antara mereka memiliki kesamaan pandangan tentang tanaman obat,

\section{Tabel 3 Luas Lahan}

\begin{tabular}{ccc}
\hline Luas Lahan & Frekuensi & $\%$ \\
\hline Dibawah $1 / 4$ ha & 65 & $58 \%$ \\
$1 / 4-1 / 5$ ha & 20 & $18 \%$ \\
1 ha/lebih & 28 & $25 \%$ \\
\hline Jumlah & 113 & $100 \%$ \\
\hline
\end{tabular}

Sumber: Data Olahan Penulis

Tabel 4 Tingkat Kategori Kohesivitas Kelompok Tani (Y)

\begin{tabular}{ccc}
\hline Kategori & Frekuensi (F) & Persentase (\%) \\
\hline Rendah & 1 & $1 \%$ \\
Sedang & 1 & $1 \%$ \\
Tinggi & 112 & $98 \%$ \\
\hline Jumlah & 114 & 100,00 \\
\hline
\end{tabular}

Sumber: Data Olahan Penulis

Tabel 5 Tabulasi Silang Relasi Jenis Kelamin dan Kohesivitas Kelompok Tani

\begin{tabular}{ccccccccc}
\hline \multirow{2}{*}{ Jenis } & \multicolumn{9}{c}{ Kohesivitas } & \multicolumn{2}{c}{ Total } \\
\cline { 2 - 7 } Kelamin & \multicolumn{2}{c}{ Rendah } & \multicolumn{2}{c}{ Sedang } & \multicolumn{2}{c}{ Tinggi } & \multicolumn{2}{c}{} \\
\cline { 2 - 8 } & $\mathrm{f}$ & $\%$ & $\mathrm{f}$ & $\%$ & $\mathrm{f}$ & $\%$ & $\mathrm{f}$ & $\%$ \\
\hline Laki-Laki & 0 & $.0 \%$ & 0 & $.0 \%$ & 34 & $100.0 \%$ & 34 & $100.0 \%$ \\
Perempuan & 1 & $1.3 \%$ & 1 & $1.3 \%$ & 78 & $97.5 \%$ & 80 & $100.0 \%$ \\
\hline Total & 1 & $0.9 \%$ & 1 & $0.9 \%$ & 112 & $98.2 \%$ & 114 & $100.0 \%$ \\
\hline
\end{tabular}

Sumber: Data Olahan Penulis 
merasa senang mengikuti kegiatan kelompok, memiliki wawasan tentang tanaman obat, selalu ada pembicaraan dan pembagian tugas yang harus dilakukan oleh anggotanya, dan selalu dikerjakan bersama-sama.

Karakteristik indiviu yang berkaitan dengan kohesivitas kelompok tani dalam penelitian ini meliputi: relasi Jenis Kelamin petani dengan kohesivitas, relasi lamanya bertani tanaman obat dan kohesivitas kelompok tani, relasi luas lahan yang dimiliki petani petani dengan kohesivitas kelompok tani.

Berdasarkan tabel 5, dapat dilihat bahwa mayoritas petani tanaman obat yang berjenis kelamin perempuan memiliki relasi yang tinggi dengan kohesivitas dalam kelompoknya, hanya $1,3 \%$ dari perempuan yang relasinya dengan kohesivitas kelompoknya rendah, sedangkan yang laki-laki 100\% memiliki relasi yang tinggi dengan kohesivitas kelompoknya.
Perbedaan relasi tersebut, tidak mencerminkan keadaan sebenarnya bahwa perempuan lebih kohesiv dibandingkan dengan petani laki-laki, karena jumlah respondennya berbeda, bahkan justru persentase petani laki-laki walaupun lebih sedikit dari petani perempuan seluruhnya $(100 \%)$ memiliki tingkat kohesivitas yang tinggi, sementara petani perempuan yang tingkat kohesivitasnya tinggi ada 97,5\%. Terlepas dari perbedaan persentase tersebut, dapat dilihat bahwa di antara para petani tanaman obat telah terbentuk kohesivitas kelompok berupa ikatan yang dapat mempersatukan mereka ke dalam satu ikatan kelompok, yang dapat menjadi kekuatan sosial untuk menyatukan dan mengikat anggotanya untuk tetap berada di dalam kelompok. Gambaran relasi lamanya bertani tanaman obat petani yang menjadi responden dengan kohesivitas kelompok tani dapat diketahui dari

Tabel 6 Relasi Lamanya bertani tanaman obat dan Kohesivitas Kelompok Tani

\begin{tabular}{cccccccccc}
\hline \multirow{2}{*}{$\begin{array}{c}\text { Lamanya } \\
\text { bertani } \\
\text { tanaman obat }\end{array}$} & \multicolumn{4}{c}{ Rendah } & \multicolumn{2}{c}{ Sedang } & \multicolumn{2}{c}{ Tinggi } & \multicolumn{2}{c}{ Total } \\
\cline { 2 - 8 } & $\mathrm{f}$ & $\%$ & $\mathrm{f}$ & $\%$ & $\mathrm{f}$ & $\%$ & $\mathrm{f}$ & $\%$ \\
\hline 1-2 Tahun & 1 & $1.2 \%$ & 1 & $1.2 \%$ & 82 & $97.6 \%$ & 82 & $100.0 \%$ \\
$3-4$ Tahun & 0 & $.0 \%$ & 0 & $.0 \%$ & 8 & $100.0 \%$ & 8 & $100.0 \%$ \\
5 tahun lebih & 0 & $.0 \%$ & 0 & $.0 \%$ & 22 & $100.0 \%$ & 20 & $100.0 \%$ \\
\hline & 1 & $.9 \%$ & 1 & $.9 \%$ & 112 & $98.2 \%$ & 114 & $100.0 \%$ \\
\hline
\end{tabular}

Sumber: Data Olahan Penulis

Tabel 7 Relasi Luas Lahan yang Dimiliki Petani Petani dengan Kohesivitas Kelompok Tani

\begin{tabular}{|c|c|c|c|c|c|c|c|c|}
\hline \multirow{3}{*}{$\begin{array}{c}\text { Luas Lahan } \\
\text { yang Dimiliki }\end{array}$} & \multicolumn{6}{|c|}{ Kohesivitas } & \multirow{2}{*}{\multicolumn{2}{|c|}{ Total }} \\
\hline & \multicolumn{2}{|c|}{ Rendah } & \multicolumn{2}{|c|}{ Sedang } & \multicolumn{2}{|c|}{ Tinggi } & & \\
\hline & $\mathrm{f}$ & $\%$ & $\mathrm{f}$ & $\%$ & $\mathrm{f}$ & $\%$ & $f$ & $\%$ \\
\hline Dibawah $1 / 4$ ha & 1 & $1.5 \%$ & 1 & $1.5 \%$ & 63 & $97 \%$ & 65 & $100.0 \%$ \\
\hline 1/4-1 ha & 0 & $0 \%$ & 0 & $.0 \%$ & 21 & $100.0 \%$ & 20 & $100.0 \%$ \\
\hline 1ha/lebih & 0 & $0 \%$ & 0 & $.0 \%$ & 28 & $100.0 \%$ & 28 & $100.0 \%$ \\
\hline Total & 1 & $9 \%$ & 1 & $.9 \%$ & 112 & $98.2 \%$ & 114 & $100.0 \%$ \\
\hline
\end{tabular}

Sumber: Data Olahan Penulis 
tabulasi silang pada tabel 6 .

Berdasarkan tabel 6, dapat dilihat bahwa ternyata mayoritas petani yang menjadi responden telah bertani tanaman obat selama 1-2 tahun, memiliki relasi kohesivitas yang tinggi (97,6\%), yang telah bertani selama 3-4 tahun dan memiliki kohesivitas tinggi ada $100 \%$. Dengan demikian, seluruhnya memiliki relasi kohesivitas yang tinggi. Namun demikian, walaupun lamanya bertani memiliki relasi kohesivitas, secara umum belum dari mereka belum lama menjadi petani tanaman obat. Artinya bahwa tingkat kohesivitas pada kelompok tani tanaman obat tidak terlalu berkaitan dengan lamanya menjadi petani tanaman obat, yang berkaitan menurut Myers (2012) adalah "perasaan "we feeling" yang mempersatukan setiap anggota kelompok menjadi satu bagian".

Deskripsi relasi luas lahan yang dimiliki petani petani yang menjadi responden dengan kohesivitas kelompok tani tanaman obat dapat diketahui dari tabulasi silang pada tabel 7.

Berdasarkan tabel 7, dapat dilihat bahwa ternyata mayoritas $(97 \%)$ petani tanaman obat yang memiliki relasi kohesivitas yang tinggi luas lahan yang dimilikinya untuk ditanami tanaman obat di bawah $1 / 4 \mathrm{Ha}$, sedangkan petani yang me $1 / 4$ - 1 ha, seluruhnya memiliki relasi kohesivitas yang tinggi. Demikian pula dengan petani yang memiliki lahan 1 ha/lebih, seluruhnya memiliki relasi kohesivitas yang tinggi.

Analisis hubungan jenis kelamin dengan kohesivitas kelompok tani menggunakan analisis korelasi theta. Hasil analisis yang didapat untuk melihat korelasi jenis kelamin dalam Kelompok (X) dengan kohesivitas kelompok tani adalah:

$\mathrm{H}_{0}: \rho=0$ (Tidak terdapat hubungan antara

Tabel 7 Relasi Luas Lahan yang Dimiliki Petani Petani dengan Kohesivitas Kelompok Tani

\begin{tabular}{|c|c|c|c|c|c|c|c|c|}
\hline \multirow{3}{*}{$\begin{array}{l}\text { Luas Lahan } \\
\text { yang Dimiliki }\end{array}$} & \multicolumn{6}{|c|}{ Kohesivitas } & \multirow{2}{*}{\multicolumn{2}{|c|}{ Total }} \\
\hline & \multicolumn{2}{|c|}{ Rendah } & \multicolumn{2}{|c|}{ Sedang } & \multicolumn{2}{|c|}{ Tinggi } & & \\
\hline & $\mathrm{f}$ & $\%$ & $\mathrm{f}$ & $\%$ & $\mathrm{f}$ & $\%$ & $\mathrm{f}$ & $\%$ \\
\hline Dibawah $1 / 4$ ha & 1 & $1.5 \%$ & 1 & $1.5 \%$ & 63 & $97 \%$ & 65 & $100.0 \%$ \\
\hline 1/4-1 ha & 0 & $.0 \%$ & 0 & $.0 \%$ & 21 & $100.0 \%$ & 20 & $100.0 \%$ \\
\hline 1ha/lebih & 0 & $.0 \%$ & 0 & $.0 \%$ & 28 & $100.0 \%$ & 28 & $100.0 \%$ \\
\hline Total & 1 & $.9 \%$ & 1 & $.9 \%$ & 112 & $98.2 \%$ & 114 & $100.0 \%$ \\
\hline
\end{tabular}

Sumber: Data Olahan Penulis

Tabel 8 Korelasi Jenis Kelamin dan Kohesivitas Kelompok Tani

Value

\begin{tabular}{cccc}
\hline Nominal by & & & \\
\hline Interval & Eta & Jenis Kelamin Dependent & 0.254 \\
\hline
\end{tabular}

Kohesivitas Kelompok Tani Dependent

0.181

Sumber: Data Olahan Penulis 
Lamanya jenis kelamin dengan kohesivitas kelompok tani)

$\mathrm{H}_{1}: \rho \neq 0$ (Terdapat hubungan antara jenis kelamin dengan kohesivitas kelompok tani) $\alpha=0.05$

Berdasarkan tabel 8 "hubungan antara jenis kelamin dalam Kelompok dengan kohesivitas kelompok tani memiliki hubungan yang positif'. Besar korelasi eta yang mendekati 0 menunjukkan bahwa terdapat korelasi yang lemah antara jenis kelamin dalam Kelompok dengan kohesivitas kelompok tani.

Analisis hubungan lamanya bertani tanaman obat dengan kohesivitas kelompok tani menggunakan analisis korelasi Rank Spearman. hipotesis yang digunakan untuk melihat korelasi Lamanya Bertani tanaman obat (X) dengan kohesivitas kelompok tani adalah:

$\mathrm{H}_{0}: \rho=0$ (Tidak terdapat hubungan antara Lamanya Bertani tanaman obat dengan kohesivitas kelompok tani)

$\mathrm{H}_{1}: \rho \neq 0$ (Terdapat hubungan antara Lamanya Bertani tanaman obat dengan kohesivitas kelompok tani)

$\alpha=0,05$

\section{Tabel 9 Nilai Korelasi Lamanya Bertani tanaman obat $(\mathrm{X})$ dengan Kohesivitas Kelompok Tani (Y)}

\begin{tabular}{ll}
\hline & Rank Spearman \\
\hline Korelasi & 0,171 \\
\hline
\end{tabular}

Sumber: Data Olahan Penulis

Berdasarkan tabel 9, hubungan antara "Lamanya Bertani tanaman obat dengan kohesivitas kelompok tani" memiliki hubungan yang positif. Besar hubungan antara Lamanya Bertani tanaman obat dengan kohesivitas kelompok tani adalah $0,171(17,1 \%)$.

Analisis Hubungan Luas lahan yang dimiliki dengan kohesivitas kelompok tani menggunakan analisis korelasi Rank Spearman. hipotesis yang digunakan untuk melihat korelasi Luas lahan yang dimiliki (X) dengan kohesivitas kelompok tani adalah:

$\mathrm{H}_{0}: \rho=0$ (Tidak terdapat hubungan antara
Luas lahan yang dimiliki dengan kohesivitas kelompok tani)

$\mathrm{H}_{1}: \rho \neq 0$ (Terdapat hubungan antara Luas lahan yang dimiliki dengan kohesivitas kelompok tani)

$\alpha=0,05$

Tabel 10 Nilai Korelasi Luas lahan yang dimiliki (X) dengan Kohesivitas Kelompok Tani (Y)

\begin{tabular}{ll}
\hline & Rank Spearman \\
\hline Korelasi & 0,320 \\
\hline
\end{tabular}

Sumber: Data Olahan Penulis

Berdasarkan tabel 10 "hubungan antara Luas lahan yang dimiliki dengan kohesivitas kelompok tani memiliki hubungan yang negatif'. Besar hubungan antara Luas lahan yang dimiliki dengan kohesivitas kelompok tani adalah $0,320(32 \%)$.

\section{HASIL DAN PEMBAHASAN}

Berdasarkan hasil penelitian, ternyata karakteristik individu berdasarkan jenis kelamin memiliki hubungan yang positif dengan kohesivitas kelompok. Petani tanaman obat, baik itu perempuan maupun laki-laki menjadi anggota suatu kelompok didasarkan pada pengalamannya selama dirinya berinteraksi dengan lingkungannya. Pengalaman tersebut membentuk pengetahuan yang nantinya menjadi dasar untuk memaknai interaksi tersebut, sehingga dirinya merasa cocok untuk masuk dan beraktivitas di dalam kelompoknya.

Jenis kelamin merupakan salah satu karakteristik yang melekat pada individu yang terbentuk akibat dari pengalamannya dalam berinteraksi, berimplikasi pada performanya ketika dirinya beraktivitas sebagai anggota kelompok tani tanaman obat, yang dapat membentuk kepribadiannya. Menurut Nimran dalam Kurniawati (2007: 17) "kepribadian dapat didefinisikan sebagai keseluruhan cara bagaimana individu bereaksi dan berinteraksi dengan orang lain".

Aktivitas dalam kelompok tani tanaman 
obat, melibatkan banyak orang yang berpartisipasi didalamnya (laki-laki dan perempuan), dimana sifat hubungan di antara mereka yang terlibat dapat mempengaruhi terhadap sikap dan prilakunya, karena mereka telah terikat dengan norma kelompoknya sehingga mereka memiliki pandangan yang sama. Hal ini sesuai dengan pendapat Rakhmat (2008), "bila sejumlah orang dalam kelompok mengatakan atau melakukan sesuatu, ada kecenderungan para anggota untuk mengatakan dan melakukan hal yang sama".

Berkaitan dengan kohesivitas ini hasil penelitian sebelumnya menunjukkan bahwa:

"Tingkat kohesivitas anggota kelompok tani tanaman obat dalam penyebaran informasi tanaman obat bagi petani tanaman obat dapat dilihat dari seluruh besar anggota kelompok tani memiliki kesamaan pandangan tentang pentingnya menanam tanaman obat dengan pihak lain .....".

Dengan demikian, jenis kelamin memiliki hubungan positif dengan kohesivitas. Tetapi bukan pada perbedaan jenis kelaminnya, melainkan pada kedua-duanya (laki-laki dan perempuan) sama-sama memiliki hubungan positif dengan kohesivitas yang disebabkan mereka kedua-duanya telah terlibat dalam suatu interaksi dalam jejaring komunikasi petani tanaman obat sehingga di antara mereka memiliki suatu ikatan yang dapat mempersatukan mereka ke dalam sebuah ikatan kelompok.

Karakteristik individu lainnya yang diduga berkaitan dengan kohesivitas adalah lamanya menjadi petani tanaman obat, dimana dari hasil penelitian ternyata "Lamanya Bertani tanaman obat memiliki hubungan yang positif dengan kohesivitas kelompok tani”. Lamanya bertani merupakan wujud pengalaman para petani dalam mengelola tanaman obat, dimana mayoritas dari mereka berkecimpung dalam tanaman obat baru 1-2 tahun.

Lamanya bertani tanaman obat bagi kelompok tani di wilayah penelitian ini tergolong masih baru, namun demikian interaksi di antara sesama anggota kelompok maupun dengan kelompok lain, dan dengan pembina intensif dilakukan, bahkan telah terbentuk jejaring komunikasi yang tinggi di antara mereka. Hal ini bisa dilihat dari hasil penelitian oleh Bakti (2015), sebagai berikut:

"Tingkat jejaring komunikasi petani tanaman obat dikategorikan tinggi. Hal ini dapat dilihat dari seringnya mereka membicarakan (berdialog) tentang masalah tanaman obat baik dalam kelompok sendiri, maupun dengan pihak luar (kelompok lain dan dengan petugas dari dinas terkait), dan mereka diberi kebebasan untuk berkomunikasi dengan pihak lain".

Lamanya bertani tanaman obat dan seringnya interaksi di dalam jejaring komunikasi tersebut merupakan proses belajar anggota kelompok tani yang dapat menjadi bekal bagi dirinya berupa pengetahuan dan keterampilan dalam menekuni usaha tani tanaman obat. Hal ini sesuai dengan pendapat Pratiwi (2010), bahwa:

"Lama bertani akan berpengaruh nyata terhadap perilaku petani dalam mengelola lahan pertaniannya, semakin lama tahun bertani maka tingkat pengalaman yang dimiliki akan semakin tinggi, dan akan memiliki perilaku dalam mengelola lahan yang baik".

Lama bertani dan keterlibatannya dalam jejaring komunikasi merupakan pengalaman bekerja yang sangat berharga dan harus dilalui oleh anggota kelompok tani. Menurut Sastrohadiwiryo (2005), "pengalaman bekerja merupakan modal utama seseorang untuk terjun dalam bidang tertentu". Pengalaman ini dapat membangun pemahaman, keahliannya, dan partisipasinya dalam mengelola tanaman obat. Hal ini sesuai dengan pendapat Nitisemito (2005):

"Pengalaman kerja merupakan suatu bagian yang penting dalam proses pengembangan keahlian seseorang, tetapi hal tersebut juga tergantung pada pendidikan serta latihan. Melalui pengalaman kerja tersebut seseorang secara sadar atau tidak sadar belajar, sehingga akhirnya dia akan memiliki kecakapan teknis, serta keterampilan dalam menghadapi pekerjaan". 
Oleh karena lama bertani berkaitan dengan pengalamn kerja, khususnya pengalaman dalam mengelola tanaman obat, maka pengalaman kerja yang diperoleh tersebut menjadikan kelompok tani sebagai wadah belajar untuk membangun dan meningkatkan pengalamannya tentang tanaman obat. Hal ini sesuai dengan pendapat (Pusluhtan, 2002):

"Kelompok tani merupakan wadah belajar mengajar bagi anggotanya guna meningkatkan pengetahuan, keterampilan dan sikap (PKS) serta tumbuh dan berkembangnya kemandirian dalam berusaha tani sehingga produktivitasnya meningkat, pendapatannya bertambah serta kehidupan yang lebih sejahtera"

Menurut Purwanto (2007), kelompok tani adalah kumpulan petani-nelayan yang didasarkan atas kesamaan, keserasian satu lingkungan sosial budaya untuk mencapai tujuan yang sama. Dengan demikian kelompok tani mempunyai ciri-ciri sebagai berikut: beranggotakan petani-nelayan, hubungan antara anggota erat, mempunyai pandangan, kepentingan yang sama dalam mengelola usaha taninya, mempunyai kesamaan jenis komoditas usaha, usaha tani yang diusahakan merupakan sebuah ikatan fungsional/bisnis, dan mempunyai tujuan yang sama.

Peningkatan kemampuan kelompok tani adalah upaya memfungsikan kelompok sebagai kelas belajar, wahana kerja sama dan unit produksi, unit penyedia sarana dan prasarana produksi, unit pengolahan dan pemasaran dan unit jasa penunjang sehingga menjadi organisasi petani yang kuat dan mandiri. Sedangkan Pusluhtan (2002) membaginya menjadi: 1). kelas belajar, 2). wahana kerjasama, 3). unit produksi.

Kelas belajar kelompok tani merupakan wadah belajar mengajar bagi anggotanya. Wadah belajar mengajar ini guna meningkatkan pengetahuan, keterampilan dan sikap (PKS) serta tumbuh dan berkembangnya kemandirian dalam berusaha tani sehingga produktivitasnya meningkat, pendapatannya bertambah serta kehidupan yang lebih sejahtera.

Wahana kerja sama kelompok tani merupakan tempat untuk memperkuat kerja sama di antara sesama petani dalam kelompok tani dan antar kelompok tani serta dengan pihak lain. Melalui kerja sama ini diharapkan usaha lainnya akan lebih efisien serta lebih mampu menghadapi ancaman, tantangan, hambatan dan gangguan.

Unit produksi usaha tani yang dilakukan oleh masing-masing anggota kelompok tani. Secara keseluruhan harus dipandang sebagai kesatuan usaha yang dapat dikembangkan untuk mencapai skala ekonomi, baik dipandang dari segi kuantitas, kualitas maupun kontinuitas.

Lama bertani yang membentuk pengalaman dalam mengelola tanaman obat yang diperoleh selama dirinya masuk dan belajar di dalam kelompok tani, sesuai dengan hasil penelitian Bakti (2015), “.....sebagian besar merasa senang mengikuti kegiatan kelompok sebagai wadah belajar mengelola tanaman obat untuk meningkatkan wawasan tentang tanaman obat.....". Dengan begitu, tumbuhnya perasaan senang dari anggota kelompok tani untuk belajar mengelola tanaman obat, maka kohesivitas kelompok tanai tanaman obat dapat terbangun. Lama bertani ini berkaitan dengan pengalaman melakukan usaha tani Tanaman obat, yang menurut Nur Asih (2009: 56), "Pengalaman berusaha tani merupakan proses belajar yang dapat mempermudah adopsi dan penerapan teknologi yang dikembangkan secara dinamis".

Karakteristik individu petani selanjutnya adalah luas lahan yang dimiliki, di mana dari hasil penelitian mayoritas responden memiliki luas lahan di bawah 1/4 ha. Luas lahan sebesar ini tergolong sempit untuk menghasilkan tanaman obat yang dibutuhkan. Hernanto (1993) menyebutkan:

"luas lahan usaha tani menentukan pendapatan, taraf hidup dan derajat kesejahteraan rumah tangga petani. Luas Penguasaan lahan akan berpengaruh terhadap adopsi inovasi, karena semakin luas lahan usaha tani maka akan semakin tinggi hasil produksi sehingga turut meningkatkan pendapatan petani”.

Namun demikian, dalam kasus pengelolaan tanaman obat, luas lahan yang digarap petani tidak luas, karena tanaman obat ini memang bukan komoditas utama. Tapi dengan luas 
lahan yang sempit ini para petani tanaman obat berusaha memanfaatkan lahan tersebut untuk bersama-sama dengan anggota kelompok yang lain, dipimpin oleh ketua kelompok, dan terkadang didampingi oleh pembina dari instansi terkait berupaya menjadikan kegiatan mengelola tanaman obat sebagai fasilitasi sosial yang digarap dan dipelihara dengan serius namun menyenangkan.

Fasilitasi sosial berupa aktivitas bersama kelompok tani yang dipimpin oleh ketua dan dibimbing oleh pembina dalam mengelola tanaman obat di lahan yang sempit ini menyebabkan semuanya menjadi mudah dilakukan. Hal tersebut menurut Rakhmat (2008) menunjukkan kelancaran atau peningkatan kualitas kerja karena ditonton kelompok. Kelompok mempengaruhi pekerjaan sehingga terasa menjadi lebih mudah".

Aktivitas pengelolaan tanaman obat oleh kelompok tani di lahan yang sempit ini menjadi mudah karena dikerjakan bersama dan disaksikan oleh kelompok berhubungan dengan kohesivitas kelompok tani. Hal ini bisa terjadi, karena sesuai dengan hasil penelitian Bakti (2015),

"....., sebagian besar para petani tanaman obat menyatakan dalam setiap kegiatan pengelolaan tanaman obat selalu ada pembicaraan dan pembagian tugas yang harus dilakukan oleh anggotanya, dan setiap kegiatan pengelolaan tanaman obat selalu dikerjakan bersama-sama"), sehingga menurut hasil penelitian Harisman (2014: 227), "karakteristik petani (luas lahan usaha tani, umur,....) memberikan pengaruh nyata terhadap kemampuan kerja sama kelompok tani”.

Dengan demikian, jenis kelamin, luas lahan, dan lamanya bertani sebagai bagian dari karakteristik individu petani berhubungan erat dengan tingkat kohesivitasnya dalam kelompok tani tersebut. Hal ini bisa dilihat dari partisipasi mereka dalam melaksanakan kegiatan kelompok secara bersama-sama.

Tingginya tingkat kohesivitas kelompok menurut Iskandar dan Caesar (2013: 56), "sangat ditentukan oleh bagaimana proses penumbuhan kelompok. Pada kelompok-kelompok yang proses penumbuhannya secara partisipatif,.... lebih kohesif".

\section{SIMPULAN}

Berdasarkan pembahasan di atas, penulis dapat menyimpulkan penelitian ini sebsagai berikut: Karaktersitik individu merupakan salah satu faktor penting dalam proses pembentukan kohesivitas kelompok tani tanaman obat. Hal ini disebabkan, karakteristik individu yang terdiri dari jenis kelamin, lamanya bertani, dan luas lahan yang dimiliki dalam pengelolaan tanaman obat, akan mencerminkan kepribadian dari mereka yang terlibat dalam kelompok tersebut yang termanifestasikan ke dalam keseluruhan cara individu tersebut bereaksi dan berinteraksi dengan orang lain, baik dengan sesama anggota kelompok, antar anggota kelompok, dan dengan pembina dari instansi terkait.

Hasil dari interaksi tersebut berakibat pada kohesivitas kelompok yang dimasukinya, di mana individu-individu dengan segala karakteristiknya tersebut yang saling berinteraksi membentuk kesamaan perasaan, yang mengarah pada pembentukan kohesivitas yang tinggi di antara kelompok tani tanaman obat, berupa kesamaan pandangan tentang pentingnya menanam tanaman obat dengan pihak lain, sebagian besar merasa senang mengikuti kegiatan kelompok sebagai wadah belajar mengelola tanaman obat untuk meningkatkan wawasan tentang tanaman obat. Selain itu, para petani tanaman obat juga menyatakan dalam setiap kegiatan pengelolaan tanaman obat selalu ada pembicaraan dan pembagian tugas yang harus dilakukan oleh anggotanya, dan setiap kegiatan pengelolaan tanaman obat selalu dikerjakan bersama-sama.

\section{DAFTAR PUSTAKA}

Bakti, I. (2015). Peran jejaring komunikasi dalam membangun kohesivitas kelompok tani di jawa barat. Jurnal Penelitian Komunuikasi, Edhu Tech, Tahun 14, Vol, No 3 Oktober

Hariadi, S. S. (2011). Dinamika kelompok. Sekolah pascasarjana universitas gadjah mada. Yogyakarta: Sekolah Pascasarjana 
Harisman, K. (2014). Pengaruh kemampuan kerja sama kelompok tani terhadap penerapan teknologi sistem of rice intensification (SRI) di kabupaten sumedang. Jurnal UINSGD. Edisi Agustus 2014. Volume VIII, no.2

Hernanto, F. (1993). Ilmu usaha tani. Jakarta: Penebar Swadaya

Iskandar, E. \& Caesar, M. R. (2103). Revitalisasi dan pemberdayaan kelembagaan masyarakat pedesaan dalam kerangka pembangunan desa partisipatif berkelanjutan. Jurnal Ilmiah 'Politea' FISIP Universitas Al-Ghifari, Vol 11 Nomor 5, Juli 2013 ISSN: 873-3741-1 22

Kurniawati, D. D. (2007). Manajemen sumber daya manusia. Jakarta: Salemba Empat

Manyamsari, I. \& Mujiburrahmad. (2014). Karakteristik petani dan hubungannya dengan kompetensi petani lahan sempit (kasus di desa sinar sari kecamatan dramaga kab. Bogor jawa barat). Jurnal Agrisep Vol (15) No. 2, 2014. Hal. 70

Mislini, (2006). Analisis jaringan komunikasi pada kelompok swadaya masyarakat: kasus ksm di desa tamansari, kabupaten bogor, provinsi jawa barat. Tesis. Bogor: Sekolah Pascasarajan IPB

Myers, D. G. (2012). Psikologi sosial jilid 2. Jakarta: Salemba Humanika

Nitisemito, A. S. (2005). Manajemen personalia (manajemen sumber daya manusia), edisi kelima, cetakan keempat belas. Jakarta: Ghalia Indonesia

Purwanto, M. S. \& Santoso, P. (2007). Penguatan kelembagaan kelompok tani dalam mendukung pembangunan pertanian di jawa timur. Malang: Balai Pengkajian Teknologi Pertanian

Pusluhtan. (2002). Dinamika kelompok tani. Jakarta: Bumi Aksara

Pratiwi, E. (2010). Perilaku petani dalam mengelola lahan pertanian di kawasan rawan bencana longsor (studi kasus desa sumberejo, kecamatan batur, kabupaten banjarnegara-jateng

Rakhmat, J, (2008). Psikologi komunikasi. Bandung: Remaja Rosdakarya

Sastrohadiwiryo, B. S. (2005). Manajemen tenaga kerja indonesia pendekatan administratif dan operasional. Jakarta: Bumi Aksara 